\title{
ŹRÓDŁA DO ZAWARTOŚCI BIBLIOTEK POLSKICH TOWARZYSTW NAUKOWYCH I UPOWSZECHNIAJĄCYCH NAUKE, NA ZIEMIACH POLSKICH W OKRESIE ZABORÓW*
}

\section{Wstęp}

Znacząca rola towarzystw naukowych (ogólnych i specjalistycznych) i upowszechniających naukę w tworzeniu bibliotek na ziemiach polskich w okresie zaborów (1795-1918) jest powszechnie doceniana. Tym większy niedosyt pozostawia wiele monografii towarzystw, z których jedne przemilczają istnienie biblioteki, inne dostrzegając ją, przedstawiają jej rolę w niewłaściwych proporcjach. Przyczyn takiego stanu rzeczy należy szukać między innymi w niedostatecznej znajomości tych źródet, które pozwalają wniknąć w zawartość księgozbiorów, nieodzownych warsztatów pracy naukowo-badawczej. Źródłami tymi są niewątpliwie inwentarze i katalogi biblioteczne, którym poświęcone są obecne rozważania. W nieznacznym stopniu źródła te ujawnia "Słownik polskich towarzystw naukowych", będący podstawowym wydawnictwem informacyjnym o zrzeszeniach działających w przeszłości na ziemiach polskich ${ }^{\dagger}$. Nie wszyscy autorzy haseł zamieszczonych w „Słowniku" widzą w inwentarzach i katalogach bibliotecznych źródła do poznania jeszcze jednego ważnego nurtu działalności towarzystw, to jest funkcjonowania biblioteki. Jako przykład można przytoczyć Towarzystwo Lekarskie Warszawskie, którego biblioteka miała kilka drukowanych katalogów, tymczasem brakuje ich w „Słowniku”. Są natomiast opracowania dotyczące biblioteki. Odmiennym przykładem jest Towarzystwo Przyrodnicze w Gdańsku, którego początki sięgają 1743 r. W „Słowniku” podano informację o katalogach, wymieniono też opracowanie na temat biblioteki. Bodajże tylko w przypadku Towarzystwa Instytutu Bibliopolicznego w Lublinie i Warszawskiego Towarzystwa Muzycznego zwrócono uwagę na rękopiśmienne katalogi. Kilka wybranych przykładów świadczy o niekonsekwencjach metodycznych w opracowaniu haset do "Słownika polskich towarzystw naukowych".

Potrzebna jest zatem możliwie pełna rejestracja istniejących źródeł drukowanych i rękopiśmiennych. Bez niej nie tylko niemożliwe jest opracowanie monografii pojedynczych towarzystw, lecz także właściwa ocena dokonań towarzystw w zakresie tworzenia bibliotek na ziemiach polskich.

* Artykuł jest fragmentem przygotowywanej rozprawy na temat badań nad księgozbiorami powstałymi na ziemiach polskich do roku 1939. 
Zanim zrealizowany zostanie postulat pełnej rejestracji odnośnych źródet, pozostaje sięganie do spisów bibliograficznych, wykazujących między innymi drukowane inwentarze i katalogi biblioteczne. Ważnym przewodnikiem po katalogach jest piętnasty tom „Bibliografii polskiej XIX stulecia” Karola Estreichera ${ }^{2}$. Uwzględnia on jednak wyłącznie druki wydawniczo samoistne opublikowane do 1900 r. Z dotychczas wydanych spisów podstawowe znaczenie ma „Bibliografia inwentarzy i katalogów księgozbiorów polskich i założonych w Polsce do 1939 roku"3. Wykazuje ona pozycje ogłoszone drukiem do $1984 \mathrm{r}$. włącznie (druki zwarte, utwory, fragmenty). Trwają też prace nad kontynuacją i uzupełnieniami do wspomnianej bibliografii, a zgromadzone opisy inwentarzy i katalogów na razie mają formę kartoteki. Równolegle do tych prac prowadzone są poszukiwania rękopiśmiennych inwentarzy i katalogów. Qbie kartoteki w znaczący sposób uzupełniają „Bibliografię inwentarzy i katalogów", a materiały w nich zgromadzone są udostępniane zainteresowanym osobom.

Spośród zebranych do tej pory drukowanych i rękopiśmiennych inwentarzy i katalogów wyłonił się interesujący zespół materiałów, pozwalających poznać strukturę wewnętrzną księgozbiorów towarzystw naukowych i upowszechniających naukę. Tylko pewna ich liczba została wykorzystana do badań nad bibliotekami towarzystw, istniejącymi na ziemiach polskich w okresie zaborów. Niniejszy artykuł ma zatem na celu zwrócenie uwagi na podstawowe źródła do zawartości księgozbiorów ${ }^{4}$. Źródła te są niestety niekompletne i nie mają jednolitego charakteru. $\mathrm{Na}$ ich kompletność miały wpływ powikłane losy bibliotek, często tworzonych, przekształcanych, bądź nawet likwidowanych w okresie niewoli narodowej. Opinia o niejednolitym charakterze spisów zawartości bibliotek wynika z faktu, iż rzadziej mamy do czynienia z wykazami całych zbiorów bibliotecznych, częściej natomiast ze spisami fragmentów zbiorów. Wśród tych ostatnich są między innymi spisy: księgozbiorów ofiarowanych bibliotekom towarzystw, dubletów przeznaczonych na wymianę lub sprzedaż, zbiorów specjalnych, protokoły rewizji i katalogi wystaw. Pod względem zasięgu chronologicznego mamy spisy zawartości tworzone od początku XIX wieku po ostatnie lata (do 1990 r.). Źródła powstające współcześnie dotyczą tych bibliotek towarzystw, które przetrwały trudny okres niewoli narodowej i działają nieprzenwanie do chwili obecnej.

We wstępie wypada jeszcze zasygnalizować kilka dalszych kwestii. Przede wszystkim tradycyjna typologia bibliotek nie pozwala traktować analizowanych placówek jako jednolitą grupę ${ }^{5}$. Najmniej wątpliwości budzą biblioteki towarzystw naukowych ogólnych i specjalistycznych, przy czym pierwsze mają charakter bibliotek naukowych, drugie - bibliotek fachowych. Najwięcej zastrzeżeń, wątpliwości i kontrowersji mogą budzić biblioteki towarzystw, których głównym celem była popularyzacja nauki. Część stowarzyszeń w różnych formach i w różnym stopniu starała się także zaznaczyć swoją obecność w rozwoju nauki polskiej. Do nich należą przede wszystkim bißlioteki towarzystw miłośników nauki.

$\mathrm{Na}$ ziemiach polskich w okresie zaborów powstawały także towarzystwa, których celem było organizowanie bibliotek i czytelni o charakterze oświatowym, takich jak Towarzystwo Czytelni Ludowych, Towarzystwo Biblioteki Publicznej w Warszawie. 
Pewna część towarzystw, szczególnie znajdujących się w zaborze pruskim, prowadziła działalność nielegalnie bądź pod pozorem samopomocy i dobroczynności, ukrywając swą pracę oświatową. Określenie rzeczywistego charakteru i zakresu działalności tych towarzystw wymaga głębszych badań.

Szczupłe ramy artykułu skłoniły autorkę do zrezygnowania z rozważań na temat wielu małych towarzystw upowszechniających naukę. Z tych samych względów pominięte zostały biblioteki polskich towarzystw działających na obczyźnie oraz biblioteki obcych towarzystw powstałych na ziemiach polskich w czasie zaborów.

\section{Źródła do zawartości bibliotek towarzystw naukowych ogólnych}

Wśród bibliotek towarzystw naukowych ogólnych najdonioślejszą rolę odegrala biblioteka warszawskiego Towarzystwa Przyjaciól Nauk (TPN), tworzona od 1802 r., otwarta do użytku publicznego w 1811 r. Towarzystwo miało charakter ogólnonarodowej akademii nauk, skupiało czołowych polskich uczonych i innych intelektualistów z wszystkich dzlelnic dawnej Polski. Jego biblioteka była nie tylko nowoczesnym warsztatem pracy naukowej członków, ale udostępniała swoje zbiory szerszej publiczności. Ponadto w nowych warunkach politycznych starała się ocalić od zapomnienia i zaprzepaszczenia dorobek narodu, nadając swoim zbiorom narodowy charakter. Liczba katalogów (23 pozycje) nie oddaje w pełni bogactwa zbiorów bibliotecznych. Zachowały się do naszych czasów przede wszystkim spisy świadczące o narastaniu zbiorów dzięki ofiarności społeczeństwa oraz repertoria druków i rękopisów ${ }^{6}$.

Wśród akt TPN zawierających rozmaite spisy książek znajduje się dziewięć rejestrów książek wlączonych do biblioteki krzemienieckiej [Towarzystwa?] Przyjaciół Nauk w 1802 r. oraz „Wiadomość o wyszłych w przedaż książkach z Biblioteki Krzemienie[ckiej Towarzystwa?] Przyjaciół Nauk" z 1803 r. z podpisem dozorcy (kierownika) biblioteki Antoniego Strzeleckiego ${ }^{7}$.

Zbiory biblioteczne powolanego w 1815 r. Towarzystwa Naukowego Krakowskiego, przemianowanego w 1872 r. na Akademię Umiejętności, w 1919 na Polską Akademię Umiejętności (PAU), wreszcie w 1952 r. na Polską Akademię Nauk (oddział krakowski), poznajemy najpierw dzięki spisom darów publikowanym w latach 1858-1861 i 1875-1890, następnie katalogom rękopisów sporządzonym przez Władysława Seredyńskiego (wyd. 1869) i Jana Czubka (wyd. 1906-1912), spisowi nabytków rękopiśmiennych (wyd. 1918) i katalogowi czasopism i wydawnictw ciągłych (wyd. 1930). Po przekształceniu PAU w Polską Akademię Nauk (PAN) krakowska Biblioteka PAN skoncentrowała swoją uwagę na dokumentowaniu zbiorów specjalnych. Obok materiałów do katalogu rękopisów (15 spisów wyd. w latach 1955-1987) publikowane są katalogi rękopisów (9 tomów wyd. w latach 1962-1991) i dokumentów pergaminowych (3 części wyd. w latach 1966-1970), katalog rycin (wyd. 1987-1991), spisy poszczególnych kolekcji rycin (wyd. 19721986), katalog atlasów (wyd. 1959), map (wyd. 1966), luźnych pieczęci (wyd. 1971), katalogi wystaw zbiorów graficznych (wyd. 1970, 1976) i wystawy „W stulecie 
założenia Akademii Umiejętności" (wyd. 1973), katalog wydawnictw ciągłych treści matematyczno-przyrodniczej (wyd. 1962). Biblioteka PAN w Krakowie, pierwsza spośród placówek kontynuujących tradycje towarzystw naukowych ogólnych, ogłosiła w 1987 r. spis 56 drukowanych katalogów własnych zbiorów autorstwa Krystyny Stachowskiej.

Dotychczas nie zarejestrowano żadnego spisu zawartości biblioteki Towarzystwa Przyjaciół Nauk w Lublinie, założonego w 1818 r.

Towarzystwo Naukowe Płockie (TNP) w latach 1820-1830 działało jako Towarzystwo Naukowe przy Szkole Wojewódzkiej w Płocku, w roku 1907 zostało reaktywowane pod obecną nazwą. Warsztatem pracy naukowej członków była Biblioteka Publiczna i Szkolna Województwa Płockiego, do której w końcu 1821 r. dołączono księgozbiór Towarzystwa. Istnieje rękopiśmienny spis zawartości Biblioteki Publicznej i Szkolnej sporządzony przed 1831 rokiem $^{8}$. Po 1945 r. starano się wykazać zbiory specjalne Biblioteki im. Zielińskich TNP: rękopisy literackie (wyd. 1956), inkunabuły (wyd. 1985), zabytki piśmiennictwa poiskiego XVI w. (wyd. 1980), nieznane Estreicherowi polonika XVII w. (wyd. 1957) oraz czasopisma, które zaczęły się ukazywać przed 1864 r. (wyd. 1956).

Wlasne zbiory biblioteczne dokumentowało istniejące od 1857 r. Poznańskie Towarzystwo Przyjaciół Nauk (PTPN). Na czternaście spisów sporządzonych w latach 1869-1918 pięć wykazuje dublety druków zwartych i czasopism. Przede wszystkim jednak Hieronim Feldmanowski w 1869 r. ogłosił katalog zbiorów w układzie systematycznym. W okresie dwudziestolecia międzywojennego powstał katalog XVI-wiecznych druków polskich (wyd. 1929), inwentarz księgozbioru Amilkara i Władysława Kosińskich przekazanego Bibliotece PTPN (1929) ${ }^{9}$, a także omówienie zawartości archiwum ksiażąt Sułkowskich przygotowane przez Jana Baumgarta (wyd. 1938, 1939). W rekopisie pozostał spis biblioteki Konstantego Sczanieckiego darowanej w $1925 \mathrm{r}^{10}$. Z powojennych spisów możemy odnotować jedynie dwa wykazy rękopisów zwiazzanych tematycznie z Poznaniem i Wielkopolska (wyd. 1972-1982) oraz spis rękopisów, starych druków i XIX-wiecznych druków dotyczących Kalisza (wyd. 1972).

Bibliotekę Towarzystwa Naukowego w Toruniu (TNT) założonego w 1875 r. katalogował między innymi ks. Sylwester Kurlandt. Opracowany przez niego w 1903 r. czternastotomowy katalog znajduje się obecnie w zbiorach rękopiśmiennych Książnicy Miejskiej im. M. Kopernika w Toruniu, podobnie zresztą jak dwa katalogi nieustalonego autorstwa: pienwszy $z$ około $1886 \mathrm{r}$., drugi - $\mathrm{z}$ początku XX $w^{11}$. Należy przy tym zaznaczyć, że w 1923 r. zbiory biblioteczne TNT przeszły, jako czasowy depozyt, do Książnicy Miejskiej im. M. Kopernika, gdzie znajdują się nadal. W zwiazku z tym dokumentacja zbiorów bibliotecznych TNT stanowi integralną część katalogów Książnicy, która jednak ze względu na swój charakter pozostaje poza zasięgiem rozważań na temat bibliotek towarzystw naukowych ogólnych.

Biblioteka Górnośląskiego Towarzystwa Literackiego w Bytomiu, założonego w 1892 r., w katalogu wydanym w 1902 r. wykazała zbiory Biblioteki Polskiej w Jassach (Rumunia). 
Zawartość księgozbioru Biblioteki Centralnej Towarzystwa Naukowego Warszawskiego (TNW), założonego w 1907 r. trudna jest do bliższego poznania na podstawie samych inwentarzy i katalogów. Z przedwojennego inwentarzai katalogu Biblioteki ocalały jedynie fragmenty, które znajdują się obecnie w Bibliotece PAN w Warszawie. Ponadto w Archiwum PAN przechowywany jest inwentarz Biblioteki sprzed 1939 r., liczący 1125 pozycji oraz spis ponad 4000 tomów książek z księgozbioru Henryka Wohla, przekazanych w $1912 \mathrm{r}^{12}$ Rozbudowana w latach 1907-1952 sieć bibliotek TNW również nie jest bogata w spisy książek włączonych do zbiorów poszczególnych placówek. Zanotowano jedynie inwentarz Biblioteki Instytutu Nauk Antropologicznych i Etnologicznych sprzed $1939 \mathrm{r}^{13}$ oraz dwa spisy książek ofiarowanych tejże Bibliotece przez Adama i Stanisława Strawińskich z Nakryszek (1922) ${ }^{14}$ i Michała Federowskiego (spis z około 1923, wyd. 1988).

Dwa spisy biblioteki założonego w 1907 r. Towarzystwa Przyjaciół Nauk w Wilnie (wyd. 1910, 1912) wykazują dublety przeznaczone do sprzedaży lub wymiany z innymi bibliotekami. „Katalog rękopisów Towarzystwa Przyjaciół Nauk w Wilnie" $z$ pienwszej połowy $X X$ wieku sporządzony został do prywatnego użytku Stanislawa Kościałkowskiego ${ }^{15}$.

Inwentarz istniejącego od 1909 r. Towarzystwa Przyjaciół Nauk w Przemyślu (wyd. 1912-1913) ujawnia nabytki włączone nieco wcześniej do zbiorów muzealnych, archiwalnych i bibliotecznych.

W uzupełnieniu obrazu bibliotek towarzystw naukowych ogólnych warto wymienić stowarzyszenie naukowe młodzieży akademickiej Uniwersytetu Wrocławskiego, działające w latach 1836-1886 pod nazwą Towarzystwa Literacko-Słowiańskiego. Biblioteka Towarzystwa miała katalogi drukowane w latach 1862 i 1872. Ponadto istnieje rękopiśmienny pierwszy inwentarz zbiorów bibliotecznych, ikonografii i medali Towarzystwa ${ }^{16}$ oraz protokół rewizji biblioteki z $1886 \mathrm{r}^{17}$

\section{Źródła do zawartości bibliotek towarzystw naukowych specjalistycznych}

Przypuszczalnie wszystkie specjalistyczne towarzystwa naukowe także dysponowały własnymi księgozbiorami fachowymi. Zarejestrowana dokumentacja pozwala sądzić, że wartościowe zbiory naukowe miały przede wszystkim towarzystwa lekarskie. Swą wysoką pozycję wśród innych bibliotek towarzystw specjalistycznych zawdzięczały one co najmniej trzem czynnikom. Po pierwsze, istniejące w XIX w. towarzystwa lekarskie, będąc ośrodkami pracy naukowo-badawczej, wypełniały do pewnego stopnia lukę spowodowaną brakiem wyższej uczelni medycznej. Po drugie, dostęp do informacji naukowej był słusznie traktowany jako nieodzowny warunek wykonywania zawodu. Po trzecie wreszcie, lekarze stanowili dość zamożną warstwę ówczesnego spoleczeństwa polskiego. Zatem nie bez znaczenia był ich udział w gromadzeniu zbiorów bibliotecznych towarzystw lekarskich, których byli członkami.

Spośród istniejących w okresie zaborów towarzystw lekarskich na czoło wysuwa się Towarzystwo Lekarskie Warszawskie (TLW) z biblioteką powstałą w $1821 \mathrm{r}$. i pięcioma spisami jej zawartości sporządzonymi w latach 1854-1886. Są wśród 
nich także spisy dubletów i dzieł treści nielekarskiej (wyd. 1864, 1886) oraz inwentarz księgozbioru dra med. Feliksa Jabłonowskiego, zapisanego w 1867 r. TLW ${ }^{18}$.

Nie udało się dotrzeć do spisu zawartości biblioteki Towarzystwa Lekarskiego Wileńskiego założonego $w 1805$ r. Znana jest natomiast zawartość biblioteki Lubelskiego Towarzystwa Lekarskiego (LTL), powołanego do życia w $1874 \mathrm{r}$. Drukowany katalog jej zbiorów ukazał się w latach 1885-1896. W rękopisie pozostaje katalog księgozbioru medycznego dra Ignacego Baranowskiego, przekazanego około $1919 \mathrm{r}$. do zbiorów $\mathrm{LTL}^{19}$. Stare druki treści medycznej Kaliskiego Towarzystwa Lekarskiego, istniejącego od $1877 \mathrm{r}$. opisane zostały w $1931 \mathrm{r}$. przez A. Czajowskiego. Drukowane katalogi zbiorów bibliotecznych miało Towarzystwo Lekarzy Galicyjskich we Lwowie (wyd. 1892) i Towarzystwo Lekarskie w Gdańsku (3 kat. wyd. w latach 1900-1907). Bibliotekę swoją miało Warszawskie Towarzystwo Higieniczne powstałe w 1898 r. Katalog tej biblioteki, wydrukowany w 1902 r. uwzględnił tylko część zbiorów. Dotychczas nie znaleziono spisu wykraczającego poza księgozbiór wydziału wychowawczego Towarzystwa, co potwierdzają przeprowadzone poszukiwania bibliograficzne.

Dysponujemy też spisami zawartości bibliotek towarzystw specjalistycznych, reprezentujących inne dyscypliny naukowe. W zakresie nauk społecznych możemy wymienić: Warszawskie Towarzystwo Muzyczne założone w 1871 r. (4 kat. wyd. w latach 1932, 1956, 1965), Towarzystwo Prawnicze we Lwowie (kat. wyd. 1887) i Kołomyi (kat. wyd. 1890), Towarzystwo Ludoznawcze w Cieszynie, działające od $1901 r^{20}$ i Polskie Towarzystwo Psychologiczne w Warszawie (rękopiśmienny katalog $z$ okoto 1927 r.) ${ }^{21}$. Nauki przyrodnicze reprezentowane są przez Towarzystwo Przyrodnicze w Gdańsku, w latach 1747-1945 występujące pod niemiecką nazwą Naturforschende Gesellschaft (3 kat. wyd. w latach 1847-1856, 1874, 1904-1914) i Towarzystwo Turystyczne, o którym będzie mowa w części artykułu dotyczącej towarzystw upowszechniających naukę. W naukach rolniczych mamy Galicyjskie Towarzystwo Gospodarskie we Lwowie (kat. wyd. 1848-1856), Towarzystwo Ogrodnicze Warszawskie (kat. wyd. 1890, rękopiśmienny spis z 189.122 oraz kat. wyd. między 1923 a 1927). Wśród towarzystw specjalistycznych zajmujących się naukami biologicznymi mamy Polskie Towarzystwo Przyrodników im. Kopernika we Lwowie (2 spisy czasopism, wyd. 1928, 1937) oraz Warszawskie Towarzystwo Przyrodników (kat. wyd. 1904).

Jest to niestety, mała liczba towarzystw specjalistycznych, których zbiory biblioteczne są bardziej lub mniej znane dzięki drukowanym i rękopiśmiennym spisom zawartości.

\section{Źródła do zawartości bibliotek towarzystw upowszechniających naukę}

Problematyka bibliotek zrzeszeń miłośników nauki, teoretycznie prosta do przedstawienia, w rzeczywistości nastręcza trudności. Płynna jest bowiem granica między zrzeszeniami miłośników a towarzystwami naukowymi, które często miały swój początek w stowarzyszeniach miłośników. Celem tych ostatnich było miłoś- 
nictwo wiedzy, sztuki, obiektów fizycznych i pojęć z pominięciem działań badawczych i wydawniczych. Analiza dorobku zrzeszeń miłośników dowodzi jednak, że nie wszystkie rezygnowały z działalności badawczej i wydawniczej, tak istotnej dla wszystkich towarzystw naukowych.

Spośród księgozbiorów zrzeszeń miłośników można by wymienić bibliotekę Towarzystwa Tatrzańskiego w Zakopanem, założonego w 1873 r., od 1920 r. działającego jako Polskie Towarzystwo Tatrzańskie (PTT) z siedzibą w Krakowie. Zbiory biblioteki zakopiańskiej o charakterze ogólnym i rekreacyjnym opracował Leopold Świerz, wydając katalog wraz z dodatkami w latach 1896-1904. Zbiory krakowskie, zapoczątkowane w 1874 r., otrzymały z czasem nazwę Centralnej Biblioteki Górskiej PTT (od 1950 r. Polskiego Towarzystwa Turystyczno-Krajoznawczego). Katalog druków zwartych i czasopism w opracowaniu Kazimierza Polaka ukazał się w $1973 \mathrm{r}$.

Skromna liczba katalogów towarzystw miłośników potwierdza tezę, że ich biblioteki nie dorównywały swą rangą bibliotekom towarzystw naukowych.

Większość specjalistycznych towarzystw naukowych, z uwagi na swój charakter, zrzeszała wąskie kręgi społeczeństwa. Z konieczności więc oddziaływanie bibliotek istniejących przy tych towarzystwach było także ograniczone.

$W$ drugiej połowie XIX $w$. zaczęły pojawiać się wielkie stowarzyszenia oświatowe tworzące biblioteki (sieci biblioteczne), których celem było krzewienie zainteresowań czytelniczych i podnoszenie poziomu kultury poprzez dostarczenie książki szerokim kręgom ludności. Inicjatywy tworzenia sieci bibliotecznych wychodziły od takich organizacji, jak Towarzystwo Czytelni Ludowych i Towarzystwo Szkoły Ludowej. Nie można też pominąć inicjatyw podejmowanych przez wiele małych i krótkotrwałych stowarzyszeń oświatowych, które nie mogą być zaprezentowane w niniejszym artykule. Proces zakładania przez stowarzyszenia oświatowe powszechnie dostępnych bibliotek przebiegał rozmaicie na terenie trzech zaborów, zależnie od okresu, w jakim były podejmowane inicjatywy.

W zaborze pruskim potężną organizacją oświatową, stawiającą sobie za główny cel szerzenie czytelnictwa w języku polskim, było Towarzystwo Czytelni Ludowych (TCL), utworzone w 1880 r. w Poznaniu. Działało na terenie Wielkopolski, Katowic, Śląska Opolskiego, Pomorza Gdańskiego, Warmii i Mazur, a także części Niemiec, nie tylko popularyzując na tych ziemiach polską ksiażkę, ale zakładając biblioteki ludowe, organizując odczyty, wykłady i wystawy książek. Do 1906 r. TCL miało 1913 bibliotek, a przed wybuchem I wojny światowej 1685, przy czym w Wielkopolsce 1022, na pozostałych ziemiach 663 biblioteki. W zestawieniu z tymi liczbami musi niepokoić znikoma liczba katalogów bibliotek i czytelni ludowych powstałych na przełomie XIX i XX w. Poszukiwania bibliograficzne odnośnie do XIX wieku nie ujawnity żadnego drukowanego spisu zawartości. Sporządzony w 1888 r. spis ksiażek biblioteki TCL w Śliwicach Wielkich ukazał się drukiem 80 lat później. Niewielki fragment księgozbioru Czytelni Ludowej w Olsztynie znany jest ze spisu książek zabranych w 1889 r. w wyniku rewizji przeprowadzonej przez Heinricha Rexa, emerytowanego burmistrza Torunia (wyd. 1889 i 1967). Dwa katalogi Biblioteki Miejskiej w Grudziądzu z lat 1910-1919 pozostają nadal wśród materiarów archiwalnych dotyczących $\mathrm{TCL}^{23}$. Drukowany katalog tej samej biblio- 
teki ukazał się w 1934 r. Jest też sześć rękopiśmiennych katalogów i inwentarzy sporządzonych w latach $1927-1939^{24}$, uzupełniających katalog drukowany. W zespole akt TCL w Grudziądzu są ponadto spisy zawartości bibliotek (punktów bibliotecznych) przy firmach „Pepege” i „Unia”, Domu Karnym i Więzieniu przy ul. Budkiewicza, salce parafialnej Stowarzyszenia Robotników Katolickich oraz w Nowej Wsi, Małym Tarpnie i Mniszku ${ }^{25}$. Placówki te były zaopatrywane przez TCL w Grudziądzu, o czym świadczą spisy sporzadzone w latach 1931-1936. W zespole TCL w Bydgoszczy znajduje się także drukowany około 1918 r. katalog Zjednoczonej Czytelni Ludowej w Nowym Mieście Lubawskim, utworzonej w 1913 r. Nie znany dotychczas katalog tej czytelni wykazuje 579 pozycji ułożonych działowo. Egzemplarz wydrukowanego około 1930 r. „Katalogu Czytelni Kobiet w Toruniu", zachowany w zbiorach Książnicy Miejskiej im. M. Kopernika, ma liczne rękopiśmienne uzupełnienia oraz informację pochodzącą od ówczesnego dyrektoraZygmunta Mocarskiego: „Dar T.C.L. W Toruniu 1930/329,26. W latach 1930-1936 wydrukowane zostały trzy katalogi bibliotek TCL w Poznaniu, przy czym pienwszy jest spisem serii „obrazów świetInych” (?) TCL przy ul. św. Marcina 37 (1930), drugi - katalogiem powieści Biblioteki TCL, bez podania adresu (ok. 1935), trzeci katalogiem literatury pięknej dla dorosłych, znajdującej się w Bibliotece TCL przy Al. Marszałka Piłsudskiego 1 (1936). Zaledwie jeden katalog mówi o zbiorach Biblioteki TCL im. Karola Miarki w Katowicach. Dwutomowy katalog rękopiśmienny powstał w $1935 \mathrm{r}^{27}$

Wydaje się, że biblioteki TCL w większości miały niewielkie księgozbiory, liczące od kilkudziesięciu do kilkuset pozycji. Przypuszczalnie tylko znaczniejsze biblioteki mialy swoje drukowane katalogi.

W zaborze austriackim większe stowarzyszenia oświatowe zaznaczyły swą aktywność biblioteczną dopiero w końcu XIX w. Szczególnie ożywioną działalność w dziedzinie organizacji bibliotek publicznych, czytelni ludowych i wypożyczalni rozwinęło na terenie Galicji i Śląska Cieszyńskiego Towarzystwo Szkoły Ludowej (TSL), powołane w $1891 \mathrm{r}$. Zarządowi głównemu TSL w Krakowie podlegały koła i związki okręgowe, działające w różnych miejscowościach. W $1892 \mathrm{r}$. TSL posiadało 5 czytelni, w 1899 - 54 czytelnie i 32 wypożyczalnie. Późniejszych danych statystycznych nie zebrano, natomiast zarejestrowano 15 katalogów placówek bibliotecznych, wydanych w latach 1910-1937. Wykazują one zbiory Książnicy Publicznej im. Ernesta Bandrowskiego w Krakowie (1930), wypożyczalni książek Krakowskiego Związku Okręgowego (1910), Publicznej Biblioteki Lwowskiego Związku Okręgowego (1912-1914), Biblioteki Miejskiej im. Józefa Szujskiego w Nowym Sączu (ok. 1912, 1913), Czytelni Naukowej TSL we Lwowie (1925), Biblioteki Koła TSL w Rzeszowie $(1913,1937)$, Miejskiej Biblioteki Naukowo-Literackiej im. Juliusza Słowackiego w Tarnowie (1910), Publicznej Biblioteki Wadowickiego Kola im. S. Staszica (1914), Ksiażnicy im. H. Sienkiewicza w Rohatynie (1925), wypożyczalni ksiaż̇ek Koła w Rudkach (1922), Biblioteki Koła (1926) i Wypożyczalni Publicznej w Tarnopolu (1933). Powyższa dokumentacja jest zadziwiająco skromna w porównaniu z powszechnie wyrażaną i udokumentowaną innymi źródłami, opinią o dużej sile działania Towarzystwa. 
Na wzorach TSL opierało swoją organizację Towarzystwo Uniwersytetu Ludowego im. Adama Mickiewicza (TUL). Głównym jego zadaniem było rozpowszechnianie wiedzy przez kursy, odczyty, pogadanki, a także zakładanie czytelni i wypożyczalni ksiażek. Aktywny był oddział krakowski TUL, założony w 1899 r., przy którym powstała zasobna biblioteka. Dwa wydania katalogu biblioteki ukazały się w 1906 i 1912 r. Ponadto znany jest drukowany katalog książek wypożyczalni TUL w Rzeszowie (wyd. 1909). Nie znaleziono informacji na temat zbiorów bibliotecznych Iwowskiego Uniwersytetu Ludowego im. A. Mickiewicza.

Towarzystwo pod nazwą: Macierz Szkolna dla Księstwa Cieszyńskiego (18851906), następnie Macierz Szkolna Księstwa Cieszyńskiego (1906-1920), na przełomie 1938/1939 miało około 100 kół. Istniejąca przy zarządzie głównym w Cieszynie Centralna Biblioteka Macierzy Szkolnej Ziemi Cieszyńskiej w 1936 r. wydała katalog działowy swoich zbiorów.

Na ziemiach polskich zaboru rosyjskiego krzewieniem i popieraniem oświaty w duchu narodowym przez prowadzenie szkół, burs, ochronek, kursów dla analfabetów oraz zakładanie bibliotek i czytelni ludowych zajęła się Polska Macierz Szkolna (PMS), jedna z największych instytucji oświatowych w Królestwie Polskim. Zalegalizowana została w czerwcu 1906 r., zawieszona w grudniu 1907 r. Potem działalność placówek założonych przez PMS przejęly częściowo osoby prywatne i legalne instytucje. Nastapił także powrót do konspiracyjnych form działania sprzed 1906 r. Wznowienie jawnej działainości Macierzy odnotowujemy w 1916 r. Wśród materiałów dotyczących bibliotecznej działalności poszczególnych kół na terenie Warszawy do wybuchu I wojny światowej nie udało się na razie odszukać katalogów bibliotek. Dotychczasowa wiedza o zawartości księgozbiorów oparta jest więc na sprawozdaniach i „Spisie tymczasowym książek polecanych kołom PMS” (wyd. 1907). W Lublinie działała Czytelnia Lubelska zorganizowana w listopadzie $1906 \mathrm{r}$. przez tamtejsze Koło PMS. W 1907 r., wskutek zawieszenia przez władze działalności PMS, Florentyna Jaworowska prowadziła ja pod własnym nazwiskiem. W celu stworzenia bibliotece korzystnych warunków od 1 IV 1908 r. F. Jaworowska zorganizowała Towarzystwo Czytelni Lubelskiej, którym kierowała do śmierci (III 1925). W 1918 r. Czytelnia Lubelska przeszła znowu pod opiekę PMS. Wydano dwa katalogi: w 1911 i 1918 r. Ważne materiały źródłowe dotyczące zbiorów bibliotek publicznych PMS na terenie ziemi lubartowskiej ujawnił w $1980 \mathrm{r}$. Jan Smolarz. Rękopiśmienne katalogi biblioteki publicznej (ok. 1909) ${ }^{28}$, następnie kółka rolniczego w Łęcznej $(1912,1914)^{29}$, biblioteki i czytelni Emilii Rylowej w Lubartowie $(1912,1915)^{30}$ oraz biblioteki i czytelni Róży Kuszell z Oersettich w Samoklęskach (1912-1914) ${ }^{31}$ są świadectwem konspiracyinej działalności bibliotekarskiej PMS na lubelszczyźnie. W Łodzi pod zarządem PMS istniała w latach 1907-1914 Biblioteka im. Stebelskich. Po zamknięciu PMS w 1908 r. Kazimierz i Maria Stebelscy uzyskali zezwolenie na osobiste jej prowadzenie jako płatnej wypożyczalni. Zawartość księgozbioru opracowana została przypuszczalnie przez Teklę Korzeniewską i ogłoszona drukiem w 1909 r.

W okresie zaborów upowszechnianiem nauki zajmowahy się także towarzystwa biblioteczne. Powstałe w 1811 r. w Lublinie Towarzystwo Instytutu Bibliopolicznego funkcjonowało na zasadzie spółki akcyjnej, której zadaniem było zgroma- 
dzenie funduszu potrzebnego do zorganizowania biblioteki naukowej i księgarni. Zawartość księgozbioru znana jest dzięki „Katalogowi książek bywszego Instytutu Bibliopolicznego Lubelskiego [...] do Biblioteki Szkoły Lubelskiej dla użytku szkół i publiczności [...] 1817 roku wcielonych" przez rektora Andrzeja Smolikowskiego ${ }^{32}$.

Jednym z wcześniejszych zrzeszeń było Towarzystwo Cieszyńskie dla Wydoskonalenia się w Języku Polskim, przekształcone w 1849 r. w Towarzystwo Czytelni Polskiej w Cieszynie. Utworzona w 1848 r. Czytelnia Polska zamknięta została w 1854 r., a następnie reaktywowana w 1861 r. jako Czytelnia Ludowa. Około 1863 r. Paweł Stalmach zapoczątkował księgę inwentarzowa, która przetrwała do dnia dzisiejszego $w$ cieszyńskich zbiorach rękopiśmiennych ${ }^{33}$. Na zbiory specjalne Czytelni (rękopisy i inkunabuły) zwrócili uwagę Wojciech Zych (1910) i Alodia Kawecka-Gryczowa (1936), publikując ich spisy.

Wyjątkową pozycję wśród towarzystw bibliotecznych zajmuje Towarzystwo Biblioteki Słuchaczów Prawa Uniwersytetu Jagiellońskiego, istniejące od $1851 \mathrm{r}$. do chwili obecnej. Dwa katalogi biblioteki wydane zostały w 1892 i 1931 r.

W 1861 r. powstała Biblioteka Dąbrowska, której twórcą było Stowarzyszenie Biblioteki i Czytelni w Dąbrowie Górniczej. Dwa tomy katalogu ukazały się w 1876 i 1881 r. Dotychczas nie zdołano ustalić bibliograficznie czy ukazał się katalog Czytelni Towarzystwa Biblioteki dla Wszystkich w Dąbrowie Górniczej, istniejącej od 1906 do 1908 r., a w latach 1910-1914 prowadzonej pod prywatną firmą C. Kozłowskiej.

Od 1870 r. istniało stowarzyszenie o nazwie Czytelnia w Wadowicach. W 1874 r. odnotowujemy drukowany "Katalog książek do wypożyczania z czytelni w Wadowicach", w 1886 r. „Katalog Biblioteki Czytelni w Wadowicach”, natomiast w 1898 r. „Katalog biblioteki Towarzystwa Czytelni w Wadowicach". Przypuszczalnie wszystkie trzy katalogi dotyczą zbiorów bibliotecznych tego samego towarzystwa, na co wskazuje dodatkowo podobna liczba pozycji w każdym z katalogów: 1123, 1128 i 1233 pozycje.

Od 1875 r. istniało we Lwowie Towarzystwo "Biblioteka Słuchaczów Prawa” Uniwersytetu Jana Kazimierza. W 1882 r. Tadeusz Heppé ogłosił katalog dzieł biblioteki wraz ze wstępem zawierającym historię Towarzystwa, rok później Henryk Kopecki - dodatek do katalogu. W "Sprawozdaniach Rady Zawiadowczej Towarzystwa" zamieszczane były spisy nowych nabytków (np. w roku adm. 1897/1898 i 1906/1907).

W 1900 r. powstało stowarzyszenie (klub naukowo-towarzyski) pod nazwą "Czytelnia Zakopiańska", które zajợło się organizacją wypożyczalni książek i czytelni czasopism. W 1902 r. ukazał się „Katalog Biblioteki Czytelni Zakopiańskiej”. W 1904 r. Czytelnia Zakopiańska została przekształcona w Towarzystwo Biblioteki Publicznej w Zakopanem. W tym samym roku nastąpiło otwarcie Biblioteki Publicznej, która do 1914 r. wydała pięć katalogów (wyd. 1904, 1905, 1908, 1913, 1914).

W Łomży od 1905 r. istniało Towarzystwo Biblioteki Publicznej. W 1906 r. zalegalizowało bibliotekę Czesławy Nieziołomskiej pn. Polska Czytelnia Publiczna. Jej księgozbiór najpierw był własnością wypożyczalni prywatnej Marii Stamirowskiej, od 1900 r. C. Nieziołomskiej. Katalog wraz z dodatkiem ukazał się w 1911 i $1913 \mathrm{r}$. 
Istniejąca od 1906 r. „Czytelnia dla Wszystkich w Łowiczu” w 1914 r. została przekształcona w Towarzystwo Biblioteki i Czytelni pn. Czytelnia dla Wszystkich. Z początkiem $1918 \mathrm{r}$. biblioteka przeszła pod tymczasowy zarząd miejscowego Koła PMS. W 1921 r. przejęły ją władze miasta i nadały nazwę: Miejska Biblioteka i Czytelnia dla Wszystkich. W styczniu 1914 r. wydrukowany został "Katalog Czytelni dla Wszystkich w Łowiczu" (z datą na karcie tytułowej: 1913).

W latach 1906-1923 działało Towarzystwo Czytelń m.st. Warszawy, którego celem było "szerzenie oświaty przez zakładanie i utrzymywanie bibliotek do użytku powszechnego". Do 1922 r. założyło 8 bibliotek i wypożyczalnię podręczników szkolnych. Trudności finansowe spowodowały rozwiazanie Towarzystwa, a jego zbiory przekazane zostały nowo powołanemu w $1923 \mathrm{r}$. Towarzystwu Bibliotek Powszechnych w Warszawie. Istnieją dwa rękopiśmienne katalogi Biblioteki Centralnej Towarzystwa Czytelń m.st. Warszawy (po 1910, 1916) ${ }^{34}$ oraz drukowany katalog Czytelni Wolskiej przy ul. Chłodnej 40 (1912).

Najwięcej źródeł dotyczy Towarzystwa Biblioteki Publicznej w Warszawie. Zgodnie ze statutem, zatwierdzonym w 1906 r., miało ono współdziałać w rozwoju nauki i oświaty przez "gromadzenie i utrzymywanie księgozbioru ze wszystkich działów literatury naukowej do użytku powszechnego". Oprócz głównego księgozbioru miało też prawo zakładania i utrzymywania oddziałów (filii) Biblioteki w różnych punktach Warszawy. Towarzystwo istniało do 1928 r., a wśród źródeł zachowały się rękopiśmienne katalogi dzieł naukowych (1908-1926), bibliografii (po 1915), książek dla młodzieży (1908-1931), czasopism (1921) i dubletów (1908-1927) ${ }^{35}$, kilkanaście spisów księgozbiorów przekazanych przez różne osoby w latach $1909-1925^{36}$ oraz katalogi i inwentarz Czytelni Naukowej przejętej przez Towarzystwo w 1907 r. (w tym 2 drukowane katalogi z lat 1907-1908 i 1911 oraz rękopiśmienny inwentarz $z$ lat $1915-1933)^{37}$,

Krótko po warszawskim Towarzystwie Biblioteki Publicznej powstały jeszcze podobne towarzystwa w Kaliszu (1907), Lublinie (1907), Kielcach (1908), Łęczycy (1908) i Sandomierzu (1909). Towarzystwo Biblioteki Publicznej w Kaliszu zawiazało się wkrótce po likwidacji Polskiej Macierzy Szkolnej, nie mogącej dalej utrzymywać Biblioteki i Czytelni Publicznej im. Adama Mickiewicza. Katalogi księgozbioru zarządzanego od $1907 \mathrm{r}$. przez towarzystwo biblioteczne ukazały się drukiem w 1913 i 1927 r. Towarzystwo Biblioteki Publicznej im. Hieronima Łopacińskiego w Lublinie postawiło sobie za cel stworzenie formy prawnej dla zabezpieczenia cennych zbiorów po profesorze lubelskiego gimnazjum $\mathrm{H}$. Łopacińskim oraz powołanie do życia biblioteki publicznej. Cel ten osiągnęło, a powołana do życia Biblioteka Publiczna im. H. Łopacińskiego w latach 1913-1917 wydała katalog rękopisów opracowany przez Aleksandra Jaworowskiego. Towarzystwo Biblioteki Publicznej w Kielcach miało prawo zakładać i utrzymywać swoje biblioteki na terenie całej guberni kieleckiej. W 1910 r. został sporządzony katalog depozytów Towarzystwa $^{38}$, a trzy księgi inwentarzowe obrazują narastanie zbiorów Biblioteki Publicznej w Kielcach w okresie międzywojennym ${ }^{39}$. Biblioteka Publiczna w Łęczycy założona w 1908 r. wydała trzy lata później, dzięki staraniom miejscowego Towarzystwa Biblioteki Publicznej, katalog ksiażek w języku polskim. Towarzystwo Biblioteki Publicznej i Czytelni im. Jana Długosza w Sandomierzu zadbało o 
oddanie do użytku biblioteki publicznej, potem sprawowało nad nią opiekę. „Katalog Biblioteki Publicznej im. Jana Długosza w Sandomierzu" ukazał się w 1937 r.

Nie natrafiono na spisy książek, które mówiłyby o zbiorach bibliotecznych innych ważnych towarzystw upowszechniających naukę, aczkolwiek wiadomo, że istniały przy nich biblioteki.

\section{Zakończenie}

Przegląd inwentarzy, katalogów i innych spisów zawartości bibliotek towarzystw naukowych oraz upowszechniających naukę na ziemiach polskich w okresie zaborów nie oddaje faktycznego stanu źródeł, trudnego zresztą do określenia na obecnym etapie prac. Odzwierciedla natomiast obraz dotychczasowych poszukiwań bibliograficznych, które będą w przyszłości kontynuowane. Uzyskane dotąd wyniki wskazują na to, że w widoczny sposób będzie narastać baza źródłowa dotycząca bibliotek towarzystw naukowych ogólnych oraz różnego rodzaju towarzystw upowszechniających naukę. Owocne mogą okazać się poszukiwania w archiwach krajowych i zagranicznych materiałów źródłowych związanych z dużymi towarzystwami oświatowymi. Przekonują o tym ujawnione już źródła związane między innymi z działalnością Towarzystwa Czytelni Ludowych, Towarzystwa Szkoły Ludowej czy Polskiej Macierzy Szkolnej. Udział tych towarzystw w procesie tworzenia bibliotek polskich w okresie zaborów był niewątpliwie dominujący.

\section{Przypisy}

${ }^{1}$ Slownik polskich towarzystw naukowych. T. 1: Towarzystwa naukowe działające obecnie w Polsce. T. 2 cz. 1: Towarzystwa naukowe $\mathbf{i}$ upowszechniające, naukę działające $w$ przeszłości na ziemiach polskich. T. 3: Towarzystwa upowszechniające naukę dzialające obecnie w Polsce. Wroctaw 19781990.

${ }^{2}$ Wyd. 2. T. 15: Katalogi. Kraków 1991.

${ }^{3}$ U. Paszkiewicz, 8ibliografia inwentarzy i katalogów księgozbiorów polskich i założonych w Polsce do 1939 roku. Cz. 1: Księgozbiory instytucjonalne w układzie topograficznym. Cz. 2: Księgozbiory prywatne w układzie abecadlowym nazwisk właścicieli. Warszawa 1990.

${ }^{4} \mathrm{~W}$ przypisach do artykułu podawane są informacje o miejscu przechowywania inwentarzy $\mathrm{i}$ katalogów mających postać rękopisów. Zrezygnowano natomiast $z$ informacji bibliograficznych o piśmiennictwie na temat dziejów poszczególnych bibliotek towarzystw. Katalogi drukowane podaje „Bibliografia” U. Paszkiewicz, zob. przyp. 3.

${ }^{5}$ Przyjmuję podzial bibliotek zgodny z "Ustawą o bibliotekach" z 9 IV 1968 r. (Dziennik Ustaw nr 12 poz, 63 rozdz. 4-7).

${ }^{6}$ Archiwum Główne Akt Dawnych w Warszawie (AGAD), Akta TPN 8, 9, 87, 99-105.

7 AGAD, Akta TPN 11, s. 54-68. Mikr. 1978. Na temat tego towarzystwa nie znaleziono żadnej informacji. Nie wykluczone, że chodzi tutaj o tworzoną wówczas bibliotekę Liceum Krzemienieckiego.

${ }^{8} \mathrm{Na}$ spis ten zwrócił uwage Czesław Gutry w pracy „Biblioteka Publiczna i Szkolna Województwa Plockiego (1820-1830)". [W:] Towarzystwo Naukowe Płockie 1820-1830, 1907-1957, Plock 1957, s. 76. W Bibliotece im. Zielińskich TNP brakuje spisu.

${ }^{9}$ Bibl. PTPN, rps 929; Biblioteka Narodowa w Warszawie (BN), Mf 37411.

${ }^{10}$ Bibl. PTPN, rps. 928; BN, Mf 37395.

${ }^{11}$ Książnica Miejska im. M. Kopernika w Toruniu (KM) rps TN 330/230, 227/229, 258. 
12 Arch. PAN, Akta TNW, jedn. 47-48.

${ }^{13}$ Biblioteka Uniwersytecka w Warszawie (BUW), rps bez sygn. s. 1-360.

${ }^{14}$ BUW, rps 315.

${ }^{15} \mathrm{BN}$, rps IV.7680. Po złożeniu artykułu do druku znaleziono w archiwum Ministerstwa Kultury i Sztuki w Warszawie „Inventarnyj katalog biblioteki Obšćestva Ljubitelej Nauk v Vil'ne” (sygn. 1443/2), spisany około 1909 r. Księga ta kończy się na pozycji inwentarzowej oznaczonej numerem 9381 (łącznie 14458 woluminów).

${ }^{16}$ Bibl. PTPN, rps 851; BN, Mf 39214.

17 Bibl. PTPN, rps 944; BN, Mf 37418.

${ }^{18}$ Arch. Paristw. m.st. Warszawy, Kanc. not. A. Dziewulskiego, Vol. 50, akt 2628/378, k. 129v-136v.

${ }^{19}$ Biblioteka Uniwersytetu M. Curie-Skłodowskiej w Lublinie rps | 4.

${ }^{20} \mathrm{Na}$ istnienje rękopiśmiennego katalogu zwróciła uwagę M. Pawlowiczowa w pracy „Książka polska i biblioteka na Śląsku Cieszyńskim w latach 1740-1920", Katowice 1986, s. 14 przyp. 14.

${ }^{21} \mathrm{BN}$, rps Akc. 315.

22 BUW, rps Akc. 2465.

${ }^{23}$ Wojewódzkie Archiwum Państwowe (WAP) w Bydgoszczy, TCL w Grudziądzu, jedn. 141, 142.

24 Tamże, jedn. 139, 140, 144-146.

25 Tamże, jedn. 147.

${ }^{26} \mathrm{KM}$, sygn. K. $8^{0} 26433353$.

${ }^{27}$ Biblioteka Śląska w Katowicach, rps 735 III.

${ }^{28}$ WAP Lublin, Lubart. Zarz. Powiat, 81.

${ }^{29}$ WAP Lublin, Kanc. Gubernat. Lubel. 1912: 6 st. III; 1914: 2 st. III.

${ }^{30}$ WAP Lublin, Kanc. Gubernat. Lubel. 1912: 6 st. III; Lubart. Zarz. Powiat. 63.

${ }^{31}$ WAP Lublin, Kanc. Gubernat. Lubel. 1912: 6 st. III; Lubart. Zarz. Powiat. 65.

32 WAP Lublin, GLW 23.

${ }^{33}$ M. Pawłowiczowa, op.cit.

${ }^{34}$ Biblioteka Publiczna m.st. Warszawy (BP), rps A.128-A.129.

${ }^{35}$ BP, rps A.201, A.212-A.225.

${ }^{36}$ BP, rps A.234, A.235, A.237, A.240, A.241, A.243-A.245.

${ }^{37} \mathrm{BP}$, rps A.236.

${ }^{38}$ Wojewódzka Biblioteka Publiczna w Kielcach, rps bez sygn., 126 k.

39 Inwentarze przechowywane są w WAP w Kielcach. Por.: L. Kowalczyk-Mroczkowska, Dzialalność Biblioteki Publicznej w Kielcach w okresie międzywojennym. - Studia Kielec. 1981 nr 3, s. 23. 